\title{
Serological and Molecular Characterisation of Virus Infecting Watermelon (Citrullus lanatus) in Adim- Biase, Cross River State, Nigeria
}

\author{
O. I. Eyong', E. E. Ekpiken ${ }^{2}$, G. M. Ubi ${ }^{3^{*}}$ and A. O. Alobi ${ }^{1}$ \\ ${ }^{1}$ Department of Forestry and Wildlife Management, Cross River University of Technology, Nigeria. \\ ${ }^{2}$ Department of Plant and Biotechnology, Cross River University of Technology, Nigeria. \\ ${ }^{3}$ Department of Genetic and Biotechnology, University of Calabar, Nigeria.
}

\begin{abstract}
Authors' contributions
This work was carried out in collaboration among all authors. Author OIE designed the study, performed the statistical analysis, wrote the protocol and wrote the first draft of the manuscript. Authors EEE and GMU managed the analyses of the study. Author AOA managed the literature searches. All authors read and approved the final manuscript.

Article Information

DOI: 10.9734/ARRB/2020/v35i1130300 Editor(s):

(1) Dr. Jin-Zhi Zhang, Huazhong Agricultural University, China.

Reviewers:

(1) Filiz Randa Zelyüt, Ankara University, Turkey. (2) Celile Aylin Oluk, Eastern Mediterranean Agriculture Research Institute, Turkey. (3) Ravindra Kumar, Siddharth University, India. Complete Peer review History: http://www.sdiarticle4.com/review-history/57872
\end{abstract}

Original Research Article

Received 08 April 2020

Accepted 12 June 2020 Published 14 November 2020

\begin{abstract}
Watermelon, Citrullus lanatus, (Thunb.) is an annual crop in the Cucurbitaceae family grown for it fruits. It nutritional and medical uses helps in combating some illnesses and maintaining good health. The production of this crop in Nigeria is seriously under threat by virus disease. A survey of some farms in Adim, Biase Local Government Area of Cross River State, Nigeria during the 2019 planting season revealed mosaic and chlorotic symptoms. Mechanical inoculation was performed on young seedlings of Cucumeropsis mannii from watermelon samples showing viral symptoms and latter tested against the universal potyvirus antiserum and further detected by RT-PCR assay using cylindrical inclusion $(\mathrm{Cl})$ primer. The amplified cDNA was cloned and the nucleotide sequence determined. The serology result showed that there was positive reaction against the potyvirus antiserum confirming it to be a potyvirus. The gene sequence analysis revealed $86 \%$ sequence identity with Algerian watermelon mosaic virus. This is the first report of Algerian watermelon mosaic virus strain infecting watermelon in Nigeria.
\end{abstract}


Keywords: ACP-ELISA; RT-PCR; watermelon; AWMV; Nigeria.

\section{INTRODUCTION}

Watermelon, Citrullus lanatus, (Thunb.) is a vining annual plant in the family Cucurbitaceae grown for its fruit. The crop is usually consumed as a fresh fruit. In Africa it is sometimes cooked before eating and may also be used as an animal feed. Watermelons have become synonymous with summer and picnics, and for good reason it has refreshing quality and sweet taste help to combat heat and provide a guilt-free, low maintenance dessert [1]. Because of its water and fibre contents, watermelon has been reported to help prevent constipation and promotes healthy digestive tract [2]. Studies have shown that watermelon is helpful in combating cancer as a result of its antioxidants properties [3]. Watermelon and watermelon juice have been shown to reduce muscle soreness and improve recovery time following exercise in athletes $[4,5,6]$.

According to reports of Turkish Statistical Institute in 2009, the estimated annual production of vegetable crops is approximately 1,42 million tons covering approximately an area of 32,900 ha. Cucurbitaceae family constitutes about $70 \%$ of the crops grown. Watermelon ranks first $(841,805$ tons), followed by melon $(103,765$ tons), cucumber $(20,890$ tons) and squash $(15,563$ tons) in world cucurbit production [7].

Nigeria has a vast abundance of land, resources and climatic variations that enable it to grow different varieties of food and cash crops in its agricultural sector. As a nation with the most immerse Agricultural sector in Africa, the local agricultural industry employs up to $70 \%$ of the local workforce and contributes about $40 \%$ of the country's GDP. One of such agribusiness that contributes to the food and economic value of the country is Watermelon farming in Nigeria. According to Wikipedia, the worldwide production of watermelon as at 2014 was 111 million metric tonnes, with China accounting for $67 \%$ of the total production. This large production rate has influenced watermelon demand positively both locally and internationally, making it a lucrative agribusiness for local farmers to venture into. With a widespread demand for the crop, watermelon farming in Nigeria is growing at a fast pace.

Viral infection has become a major threat to the quantity and quality of production of this crop.
Research has shown that over 60 viruses can infect plants in the Cucurbitaceae family, and new virus species on these hosts are described every year $[8,9,10]$. The most encountered of them include Cucumber mosaic virus (CMV, genus Cucumovirus), Zucchini yellow mosaic virus (ZYMV, genus Potyvirus), Papaya ringspot virus (PRSV, genus Potyvirus), and Watermelon mosaic virus (WMV, genus Potyvirus) are the most frequent and economically important viruses on a worldwide basis [8]. Several of these viruses have been isolated and identified worldwide including Nigeria. For example, [11] has reported infection of fluted pumkin by CMV in northern Nigeria. [12] have also provided a checklist of viruses prevalent in south west of Nigeria. [13] have further reported infection of cucumber by PRSV and infection of Cucurbita moschata by Morroccan watermelon mosaic virus (MWMV) in Calabar Southern Nigeria [14]. [10] have also reported a new species of virus called Telfairia severe mosaic virus infecting Telfairia occidentalis and Algerian watermelon mosaic virus infecting cucumber [15] in Calabar. However, these studies have not been done extensively at serological and molecular level. Therefore this study is aimed at employing serological and molecular tools in identifying the virus responsible for infection of watermelon. This paper reports ACP-ELISA testing and sequence analysis of the gene of the watermelon virus isolate obtained from Adim in South South Nigeria.

\section{MATERIALS AND METHODS}

\subsection{Virus Sources and Mechanical Inoculation}

Three infected leaf samples of watermelon showing typical virus-like symptoms of mosaic and chlorotic spots were obtained from Adim, Biase Local Government Area of Cross River State Nigeria and collected into Ziploc air tight polyethylene bags to keep the leaves fresh and ensure the viability of the virus. The virus was thereafter maintained on five young seedlings of Cucumeropsis mannii through mechanical inoculation by triturating the symptomatic virus infected leaf tissues in pre-sterilized cold mortar and pestle using phosphate buffer of $8.0 \mathrm{pH}$ and $0.03 \mathrm{M}$ 


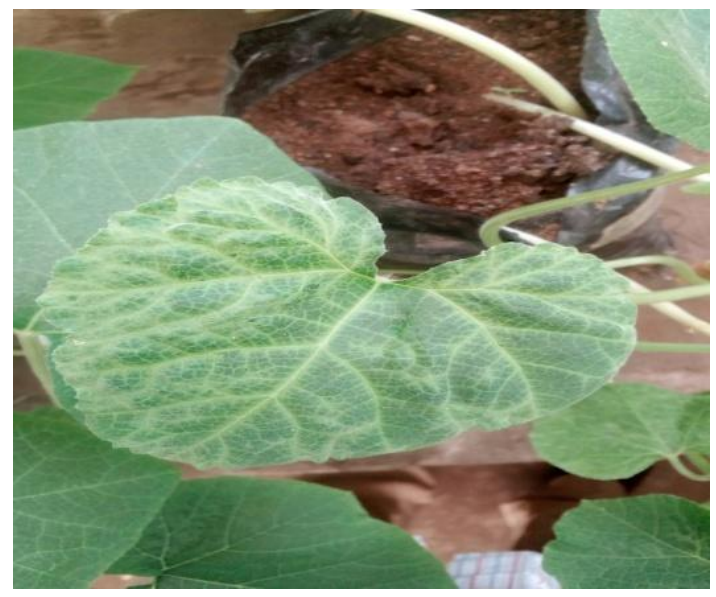

Fig. 1. Mosaic symptoms on C. mannii (The indicator plant used in maintaining the virus after isolation from the field)

\subsection{Serological Tests}

Antigen coated plate enzyme linked immunosorbent assay (ACP-ELISA) as described by [16] was used for the detection of potyvvirus. $0.1 \mathrm{~g}$ of infected leaf sample of Cucumeropsis mannii which served as indicator plant was triturated in $1 \mathrm{~mL}$ of coating buffer $\left(0.015 \mathrm{M} \mathrm{Na}_{2} \mathrm{Co}_{3}+0.0349 \mathrm{M} \mathrm{NaHCo} 3+\mathrm{dH}_{2} \mathrm{O}\right)$ and dispensed into each well of ELISA plate. After incubation at $37^{\circ} \mathrm{C}$ for $1 \mathrm{~h}$ the plate was washed 3 times with PBS-Tween for $3 \mathrm{~min}$ between each wash. Cross adsorption was made by grinding $1 \mathrm{~g}$ of healthy plant sample in $20 \mathrm{~mL}$ of conjugate buffer (1/2 PBS $+0.05 \%$ Tween 20 $+0.02 \%$ egg albumin $+0.2 \%$ PVP). The universal potyvirus antiserum was diluted at $1: 3000$ in the adsorption solution and $100 \mu \mathrm{L}$ of the antiserum polyclonal antisera was added to wells of the ELISA plates and again incubated at $37^{\circ} \mathrm{C}$ for $1 \mathrm{~h}$. The ELISA plates were then washed 3 times with PBS-T. One hundred- $\mu \mathrm{L}$ of protein, A-alkaline phosphatase conjugate diluted in the ratio $1: 15000$ in conjugate buffer (1/2 PBS $+0.05 \%$ Tween $20+0.02 \%$ egg albumin $+0.2 \%$ PVP $+0.02 \mathrm{~g} \mathrm{NaNO}_{3}$ ) was added per well and the plates incubated at $37^{\circ} \mathrm{C}$ for $1 \mathrm{~h}$. The plates were again washed 3 times with PBS-T. One hundred- $\mu \mathrm{L}$ of $0.001 \mathrm{~g} \cdot \mathrm{mL}^{-1}$ of $p$-nitrophenyl phosphate substrate in substrate buffer $(97 \mathrm{~mL}$ diethanolamine $+800 \mathrm{~mL} \mathrm{H}_{2} \mathrm{O}+0.2 \mathrm{~g} \mathrm{NaNO}_{3}$ and $\mathrm{HCl}$ to give $\mathrm{pH}$ 9.8) was added per well and incubated at room temperature for $1 \mathrm{~h}$. For all incubations, plates were covered with ELISA cover plates to avoid edge effects and to maintain uniform temperature. Healthy plant sample was used as controls. After $1 \mathrm{~h}$ absorbance was measured at $\mathrm{A}_{405 \mathrm{~nm}}$ using an ELISA plate reader (Micro Read 1000 ELISA Plate Analyser, U.S.A) after $1 \mathrm{~h}$ of incubation. The samples were considered positive when the ELISA reading was at least twice the reading for the healthy control [16].

\subsection{Rna Extraction from Infected Leaf Samples}

Total nucleic acid was obtained from infected leaves of Cucumeropsis mannii which served as indicator plant using the cetyltrimethylammonium bromide (CTAB) protocol as described by [17]. $100 \mathrm{mg}$ of each infected leaf sample was grounded in sterile mortar and pestle in $1 \mathrm{ml}$ extraction buffer (100 mMTris-HCl, pH 8.0; $1.4 \mathrm{M}$ $\mathrm{NaCl} ; 20 \quad \mathrm{mM}$ EDTA; $2 \% \quad$ CTAB) (hexadecetyltrimethylammonium bromide); and $0.4 \% \beta$ - mercaptoethanol, added just before use. Each of the homogenates was transferred into a new $1.5 \mathrm{ml}$ sterile tube. The tubes were vortexed briefly, incubated in a $60^{\circ} \mathrm{C}$ water bath for $10 \mathrm{~min}$ and allowed to cool to room temperature. Then $750 \mu$ l of phenol-choloform-isoamyl alcohol (PCl) (25:24:1) was added to each tube containing the homogenate. Each tube was then vortexed vigorously to form an emulsion and then centrifuged at the speed of $12000 \mathrm{~g}$ for $10 \mathrm{~min}$. The supernatant was then transferred to a clean $1.5 \mathrm{ml}$ tube. $300 \mu \mathrm{l}$ of cold isopropanol was added to the supernatant to precipitate the nucleic acid and the mixture was kept at $-80^{\circ} \mathrm{C}$ for 10 minutes. The mixture was centrifuged at $12,000 \mathrm{~g}$ for $10 \mathrm{~min}$ to precipitate the nucleic acid. The supernatant was discarded and the nucleic acid pellet washed in $500 \mu \mathrm{l}$ of $70 \%$ ethanol and centrifuged at $12,000 \mathrm{~g}$ for $5-10 \mathrm{~min}$. The supernatant was decanted and the resultant nucleic acid pellet was air-dried at room temperature. Nucleic acid pellet was then resuspended in $50 \mu \mathrm{l}$ sterile distilled water and used as a template source for reverse transcriptase polymerase chain reaction (RTPCR). Nucleic acid extracts from the leaves of healthy plants were used as negative control.

\subsection{Reverse Transcriptase Polymerase Chain Reaction (RT-PCR)}

Virus-specific complementary DNA (cDNA) were synthesized from total nucleic acid derived from the infected leaf of Cucumeropsis mannii used to maintain the virus isolated from watermelon by RT-PCR method as described by [18]. The RTPCR was performed using the cylindrical inclusion $(\mathrm{Cl})$ primer. 
Forward

CICP

GGIVVIGTIGGIWSIAARTCIAC-3'),

Reverse

CICP 3 (5 ACICCRTTYTCDATDATRTTIGTIGC-

$3)$ as described by [17]. The RT-PCR reaction mixture $(50 \mu \mathrm{l})$ consisted of $1 \mu \mathrm{l}$ each of CICP 5 and CICP 3, 5x Go Taq green buffer $(10.0 \mu \mathrm{l})$, $\mathrm{MgCl}_{2} \quad$ (3.0), dNTPs (1.0 $\left.\mu \mathrm{l}\right)$, Reverse transcriptase $(0.24 \mu \mathrm{M})$, Taq DNA polymerase (Promega, USA) $(0.24 \mu \mathrm{M})$, sterile distilled water $(30.52 \mu \mathrm{l})$ and nucleic acid from infected sample (1:10 dilution) (3.0 $\mu \mathrm{l})$.Amplifications were carried out in a GeneAmp 9700 PCR system thermalcycler (Applied Biosystem Inc., USA) using the following thermocyclic conditions; $42^{\circ} \mathrm{C}$ for 30 min for cDNA synthesis, $94^{\circ} \mathrm{C}$ for 3 min for initial denaturing, followed by 40 cycles of denaturing at $94^{\circ} \mathrm{C}$ for $30 \mathrm{~s}$, an annealing step at $40^{\circ} \mathrm{C}$ for $30 \mathrm{~s}$, an extension at $68^{\circ} \mathrm{C}$ for $1 \mathrm{~min}$ and a final extension at $72^{\circ} \mathrm{C}$ for 10 min ended the RT-PCR reaction. The PCR products were separated on $1.5 \%$ agarose gel, subsequently stained with ethidium bromide, visualized under UV light and photographed RT-PCR assay produced a PCR amplicon of expected size (approximately $700 \mathrm{bp}$ ).

\subsection{Amplicon Purification Sequencing}

and

The RT-PCR amplicon for the infected sample was purified by adding $95 \%$ ethanol to $40 \mu \mathrm{l}$ of the amplicon in a new $1500 \mu \mathrm{l}$ steril tube and the solution was kept in $-80^{\circ} \mathrm{C}$ for 10 minutes. The tube was centrifuged for $10 \mathrm{~min}$ and the supernatant discarded. $500 \mu \mathrm{l}$ of $70 \%$ ethanol was added and centrifuged at maximum speed for $5 \mathrm{~min}$. The supernatant was discarded and the tube was left at room temperature to dry after which the purified product was dissolved in $30 \mu \mathrm{l}$ of sterile Distilled water. Sequencing was done by using Sanger sequencer (Applied Biosystems $A B I 310)$ at INQABA Biotec West Africa Ibadan, Nigeria.

\subsection{Sequence Analysis}

The virus identity under study was established after comparing sequence of the virus with known virus sequences in the GenBank available at National Center for Biotechnology Information (NCBI) using the basic local alignment search tool (BLASTn) program [19].

\section{RESULTS}

The ACP-ELISA test result revealed a positive reaction against the universal potyvirus antiserum. The optical density reading for the potyvirus at $\mathrm{A} 405 \mathrm{~nm}$ was 1.885 which is twice greater than 0.405 the absorbance from the healthy controls (Table 1 ).

\subsection{Gene Sequence Alignment and Analysis}

The fragment of the predicted size of $700 \mathrm{bp}$ was obtained by RT-PCR with cylindrical inclusion (Cl) primer. Sequence alignment showed that the watermelon virus isolate has $86 \%$ nucleotide sequence identity with Algerian watermelon mosaic virus (EU410442.1) (Fig. 2).

\section{DISCUSSION}

In this study, a virus Algerian watermelon mosaic virus (AWMV) isolated from a naturally infected watermelon (Citrullus lanatus (Thunb.) plant exhibiting mosaic and chlorotic spot symptoms and was characterized serologically and molecularly. The serology test was performed using ACP-ELISA, the virus when inoculated on the indicator plant (Cucumeropsis manni) showed symptoms of mosaic and leaf malformation/deformation and further reacted positively against the universal potyvirus antiserum.

Table 1. Antigen coated plate (ACP) enzyme linked immunosorbent assay (ELISA) for detection of potyvirus

\begin{tabular}{|c|c|c|}
\hline Sample & Location & $\begin{array}{l}\text { OD reading at } A_{405 \mathrm{~nm}} \text { against virus polyclonal } \\
\text { antibodies }\end{array}$ \\
\hline & Adim & Potyvirus \\
\hline $\begin{array}{l}\text { Watermelonvirus isolate } \\
\text { Healthy control }\end{array}$ & & $\begin{array}{l}1.885^{*} \\
0.405\end{array}$ \\
\hline
\end{tabular}




$\begin{array}{llll}\text { Score } & \text { Expect } & \text { Identities } & \text { Gaps } \\ 693 \text { bits }(768) & 0.0 & 515 / 600(86 \%) & 5 / 600(0 \%)\end{array}$

Query 94 TGTGTGACGATGTATGTACTCTGCTGCTAGGGGACCCATTTAATCCAAACCCAACAATTC 153 ||||||| | ||||| | | |||| ||||||||||||| |||| ||| || |||||||

Sbjct 4227 TGTGTGAAAACGTATGCAAACAACTGCGAGGGGACCCATTCAATCAAAATCCCACAATTC 4286

Query 154 GTATGCGTGTAATGAATTCGTTTGGTTCATCCCCCATAACCATTATGACTAGTGGGTTTG 213 | ||||||| ||||| || |||||||||||||| | || |||||||| ||||| ||||

Sbjct 4287 GCATGCGTGGAATGACATCATTTGGTTCATCCCCTGTGACTATTATGACGAGTGGTTTTG 4346

Query 214 CGCTACACTATTTCGCACACAACGTGTATCAGCTTCAAGAATTTGATTTCATAGTCATTG 273

|||||||||| ||||||||| || ||| ||||||||||| || ||||||||||||| ||||||

Sbjct 4347 CGCTACACTACTTCGCACATAATGTGGATCAGCTTCAGGAGTTTGATTTCATAATCATTG 4406

Query 274 ATGAATGTCATGTTATAGATGCCCAAGCAATGGGATTTTATTGCCTAGCCCACGAACATA 333

|||||||||| |||||||||||||||||| ||||||||||| |||||||| ||||||||| |

Sbjct 4407 ATGAATGTCACGTTATAGATGCCCAAGCGATGGGATTTTACTGCCTAGCTCACGAACACA 4466

Query 334 AGATCAGAGGGAAATTCTCAAGGTTTCAGCAACTCCACCTGGGAGAGAAACTGAGTTCA 393

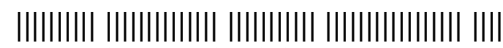

Sbjct 4467 AGATCAGAGGAAAAATTCTCAAGGTCTCAGCAACTCCGCCTGGGAGAGAAACTGAATTCA 4526

Query 394 CAACTCAGTTTCCAGTCAAGCTGGTGACAGAAGATCATATTAGCTTTCAGCAACTCGTTA 453

|||||||||||||||| ||||| |||||| |||||||||||| |||||| |||||||||||| |

Sbjct 4527 CAACTCAGTTTCCAGTTAAGCTAGTGACTGAAGATCATATCAGCTTCCAGCAACTCGTCA 4586

Query 454 ACAACTTTGGGAGTGGAGCAAACAGCGATGTCACAAGTGAAGCGGATAATATTCTCATTT 513

||||||||||| ||||||||||||||| || |||||| || ||||||||||||||||||||||||

Sbjct 4587 ACAACTTTGGAAGTGGAGCAAACAGTGACGTCACGAGCGAAGCGGATAATATTCTCATTT 4646

Query 514 ACGTCGCGAGTTATAATGAAGTTGACCAGCTAGGCAACATGCTGAATGAGAAGGGTTACA 573 ||||||| || || |||||||| |||||| |||||||| ||| |||| || ||||||||| |

Sbjct 4647 ACGTCGCTAGCTACAATGAAGTCGACCAACTAGGCAATATGTTGAACGAAAAGGGTTATA 4706

Query 574 GAGTCACAAAGGTTGATGGACGCACAATGAAAATTGGCAAAACTGAAATTCAAACATCAT 633 ||||||||||||||||||||||||||||||||||||||||||||||||||||||||||

Sbjct 4707 CAGTGACAAAAGTTGACGGACGCACAATGAAAATTGGCAAGACAGAAATTCAGAC-GCAT 4765

Query 634 AGGAACTCAAGGATAAGGGAAACATTTCATCGTTGCCACCAACATCATCGAAAACGGCGT 693

|||||| || ||||| ||| |||||||| ||||| || || || || || || || ||

Sbjct 4766 -GGAACT-AAAGATAA--GAAGCATTTCATTGTTGCTACYAAYATYATTGARAATGGAGT 4821

Fig. 2. Sequence alignment of watermelon virus isolate from Adim showing $86 \%$ percent identity with Algerian watermelon mosaic virus (EU410442.1)

Query - Gene sequence of watermelon virus isolate

Sbjct - Algerian watermelon mosaic virus

ACP-ELISA has been employed as a tool in the detection of virus into genus taxon $[20,21,22,4]$. The detection of the virus isolate in this study by universal potyvirus antiserum therefore confirms that the virus isolate is a Potyvirus. $[10,15]$ have also employed ACP-ELISA in the detection of TeSMV and strain of AWMV which are potyviruses infecting Telfairia occidentalis and Cucumis sativus respectively.

It has been suggested by $[23,24,25]$ that virus sequence with less than approximately $76 \%$ sequence identity should be regarded as belonging to different species while isolates with $76-89 \%$ sequence identity should be considered as virus of the same strains and sequence presenting $90-100 \%$ sequence identity should be regarded as same virus. The virus isolated from watermelon in this study had $86 \%$ sequence identity falling between the thresh hold of $76-89 \%$ and is however considered a strain of AWMV in Nigeria. $[10,15,26,27]$ have reported the identification of plant viruses using these criteria. This is the first report of AWMV in Nigeria. 


\section{CONCLUSION}

This study has provided information on the identity of a virus known as Algerian watermelon mosaic virus infecting watermelon in Nigeria. It has further provided information that will form the basis of sustainable management strategies against viruses and the diseases it causes on cucurbits in Nigeria. More importantly, it also provided a first step approach in developing a program for producing transgenic crops with resistance to multiple virus infections for farmers in Nigeria. This is of particular importance in terms of genetically variable virus strains being able to overcome strain-specific resistance in an introduced transgenic cultivar, hence nullifying considerable time consuming and costly efforts in resistance development.

\section{COMPETING INTERESTS}

Authors have declared that no competing interests exist.

\section{REFERENCES}

1. Bailey LB. Three discussions in Cucurbitaceae. Gentes Herbarum. 2016;2: 175-186.

2. Dane F, Liu J. Diversity and origin of cultivated and citron type watermelon (Citrullus lanatus). Genetic Resources and Crop Evolution. 2007;54:1255-1265.

3. Rimando AM, Perkins-Veazie PM. Determination of citrulline in watermelon rind. Journal of Chromatography. 2005;1078:196-200.

4. Zhe $\mathrm{C}$, Zhang $\mathrm{M}$, Zhou $\mathrm{X}$, Wu J. Development and detection application of monoclonal antibodies against Zucchini yellow mosaic virus. Journal of Intergrative Agriculture. 2017;16(1):115-124.

5. Chomicki G, Renner SS. Watermelon origin solved with molecular phylogenetics including Linnaean material: Another example of museomics. New Phytologist. 2014;205(2):526-32.

6. Renner SS, Sousa A, Chomicki G. Chromosome numbers, Sudanese wild forms and classification of the watermelon genus Citrullus, with 50 names allocated to seven biological species. Taxon. 2017;66(6):1393-1405.

7. Anonymous. TurkStat, Agricultural Structure, Production, Price, Value; 2009. (Accessed: 15 December 2013)
Available:http://tuikapp.tuik.gov.tr/bitkiselap p/bitkisel.zul

8. Lecoq $\mathrm{H}$, Desbiez C. Cucurbit viruses in the Mediterranean Region: An everchanging picture. Advances in Virus Research. 2012;84:67-126.

9. Romay G, Lecoq H, Geraud-Pouey F, Chirinos DT, Desbiez C. Current status of cucurbit viruses in Venezuela and characterization of Venezuelan isolates of Zucchini yellow mosaic virus. Plant Pathology. 2014;63:78-87.

10. Eyong OI, Owolabi AT, Mofunanya AAJ, Ekpiken EE. Biological, serological and molecular characterisation of a new virus species infecting Telfairia occidentalis in Calabar, Southern Nigeria. Journal of Experimental Agriculture International. 2020a;42(1):23-33.

11. Atiri Gl. An isolate of Cucumber mosaic virus from fluted pumpkin in Nigeria. Journal of Phytopathology. 1985;3:4-5.

12. Ayo-John El, Hughes JD. Identification of Cucumber mosaic virus infecting Musa spp. and vegetable crops in Nigeria. International Journal of Virology. 2014;10: 204-210.

13. Owolabi AT, Rabenstein F, Ehrig F. A strain of Papaya ringspot virus naturally infecting cucumber (Cucumis sativus L.) in Calabar, South Eastern Nigeria. Nigerian Journal of Botany. 2008;21(1):97-108.

14. Owolabi AT, Rabenstein F, Taiwo MA, Ehrigh F, Maiss E. Characterization and identification of a potyvirus causing mosaic disease of Cucurbita moschata Duch Ex. Poir in Calabar, South East Nigeria. International Journal of Plant Pathology. $2011 ; 2(4): 165-176$.

15. Eyong OI, Owolabi AT, Ekpiken EE, Effa EA. First report of Algerian watermelon mosaic virus infecting Cucumis sativus $L$ in South South Nigeria. Journal of Biotechnology and Biochemistry. 2020b;42(1):23-33.

16. Kumar. Methods for the diagnosis of plant virus disease. IITA Ibadan, Laboratory Manual; 2009.

17. Abarshi MM, Mohammed IU, Wasswa P, Hillocks RJ, Holt J, Legg JP, Seal SE, Maruthi MN. Optimization of diagnostic RTPCR protocols and sampling procedures for the reliable and cost-effective detection of Cassava brown streak virus. Journal of Virology Methods. 2010;163(2):353359. 
18. Pappu S, Brand R, Pappu H, Rybicki E, Gough K, Frenkel M, Niblett C. A polymerase chain reaction method adapted for selective amplification and cloning of 3 sequence of potyviral genomes: Application to Dasheen mosaic virus. Journal of Virological Methods. 1993;41:9-20.

19. Camacho C, Coulouris G, Avagyan V, Ma N, Papadopoulos J, Bealer K, Madden TL. BLAST+: Architecture and applications. BMC Bioinformatics. 2008;10:421.

20. Shang $\mathrm{H}$, Xie $\mathrm{Y}$, Zhou X, Qian $\mathrm{Y}$, Wu J. Monoclonal antibody-based serological methods for detection of Cucumber green mottle mosaic virus. Virology of Journal. 2011;8:228.

21. Wulandari DR, Ermayanti TM. Detection of potyvirus using RT-PCR and ACP-ELISA of Dioscorea species and in vitro shoot multiplication of the virus free plants. Annales Bogoriences. 2011;15(2):5678.

22. Wu JX, Ni YQ, Liu H, Ding M, Zhou XP. Monoclonal antibody-based serological assays and immunocapture RT-PCR for detecting Rice dwarf virus in field rice plants and leafhopper vectors. Journal of Virological Methods. 2014;195:134-140.

23. Shukla DD, Ward CW. Amino acid sequence homology of coat proteins as a for identification and classification of the potyvirus group. Journal of Genetic Virology. 1988;69:2703-2710.

24. King AM, Lefkowitz E, Adams MJ, Carstens EB. Virus taxonomy: $9^{\text {th }}$ report of the international committee on taxonomy of viruses. Elsevier Academic Press, San Diego; 2011.

25. Frenkle MJ, Ward CW, Shukla DD. The use of 3' non-coding nucleotide sequences in the taxonomy of potyviruses: Application to watermelon mosaic virus 2 and soybean mosaic virus-N. Journal of General Virology. 1989;70:2775-2783.

26. Yakoubi S, Desbiez C, Fakhfakh H, WipfScheibel C, Marrakchi M, Lecoq $H$. Biological characterization and complete nucleotide sequence of a Tunisian isolate of Moroccan watermelon mosaic virus. Archives of Virology. 2008;153:117-125.

27. Lecoq $\mathrm{H}$, Jane R. Zucchini yellow mosaic virus. Plant Pathology Journal. 2001;46: 809-829.

(C) 2020 Eyong et al.; This is an Open Access article distributed under the terms of the Creative Commons Attribution License (http://creativecommons.org/licenses/by/4.0), which permits unrestricted use, distribution, and reproduction in any medium, provided the original work is properly cited. http://www.sdiarticle4.com/review-history/57872 